\title{
Biostatistik Sidat Perak Danau Poso
}

\section{Daniel Limbong ${ }^{1,2}$, Martho Harry Melumpi ${ }^{1}$, Yunober Mberato ${ }^{1,2}$, Falerianus Dosi ${ }^{3}$}

\begin{abstract}
Indonesian waters has high level of eel biodiversity, which is recognized as the origin of the world eels. Poso Lake is one of the most abundant eel habitat, located in central part of Sulawesi Island. Like most of eels populations worldwide, the population in this lake has been declining and the causes are still uncertain. Very few studies had been undertaken regarding the eel population including the population in Poso Lake environment. As a response to an urgent need for research on the population biology of Poso Lake eel, the present study was conducted to provide base line information on silver eels or mature eels which captured during their on set spawning migration out of Poso Lake. A total of 100 eels which have silver eel characters were collected from weirs along the out let of Poso Lake over the study period. The sizes of eels captured ranged from 48,9$136,8 \mathrm{~cm}$ with mean $78,3 \mathrm{~cm}$ in total length, and $265-7025 \mathrm{~g}$ with mean $1289 \mathrm{~g}$ in body weight. Among them only 63 eels had gonadosomatic index (GSI) $>1 \%$, had been determined as $A$. celebesensis (41) and $A$. marmorata (22), and they were all female. GSI values of $A$. celebesensis were significantly higher than $A$. marmorata. There were no apparent differences in the condition factor of the two eels species.
\end{abstract}

Keywords: Silver eel, Poso Lake, Indonesia.

\section{Pendahuluan}

Sidat (Anguilla spp) memiliki pola hidup katadromous yang artinya mengawali hidup di laut dalam, bertumbuh di perairan tawar, dan setelah matang kelamin akan kembali beruaya ke laut untuk memijah. Selain memiliki pola hidup yang unik, sidat juga populer sebagai makanan yang mewah karena memiliki nilai nutrisi yang baik. Meskipun perairan Danau Poso (Gambar 1) telah dikenal sebagai salah satu sentra produksi sidat, namun informasi ilmiah tentang keberadaan sidat dan tingkat pemanfaatannya belum banyak diungkapkan. Semakin menurunnya hasil tangkapan sidat dari perairan ini, merupakan suatu pertanda bahwa penelitian yang mendasar tentang berbagai aspek kehidupannya perlu sedini mungkin dilaksanakan. Penguasaan pengetahuan tentang daur hidup dan habitat sidat yang kompleks, merupakan kunci menuju pemahaman atas berbagai persoalan terkait penurunan hasil tangkapan sidat tersebut. Hal ini, menjadi semakin penting, mengingat

\footnotetext{
${ }^{1}$ Fakultas Pertanian, Universitas Kristen Tentena.

2 Lembaga Penelitian dan Pengabdian Kepada Masyarakat, Universitas Kristen Tentena.

${ }^{3}$ Fakultas Keguruan Ilmu Pendidikan, Universitas Kristen Tentena.
} 
masih banyak komponen pemangku kepentingan yang belum memahami bahwa induk sidat bermigrasi dari Danau Poso menuju ke laut untuk memijah, dan anak sidat yang dihasilkan akan menempuh perjalanan yang penuh resiko untuk kembali ke habitatnya di perairan Danau Poso.

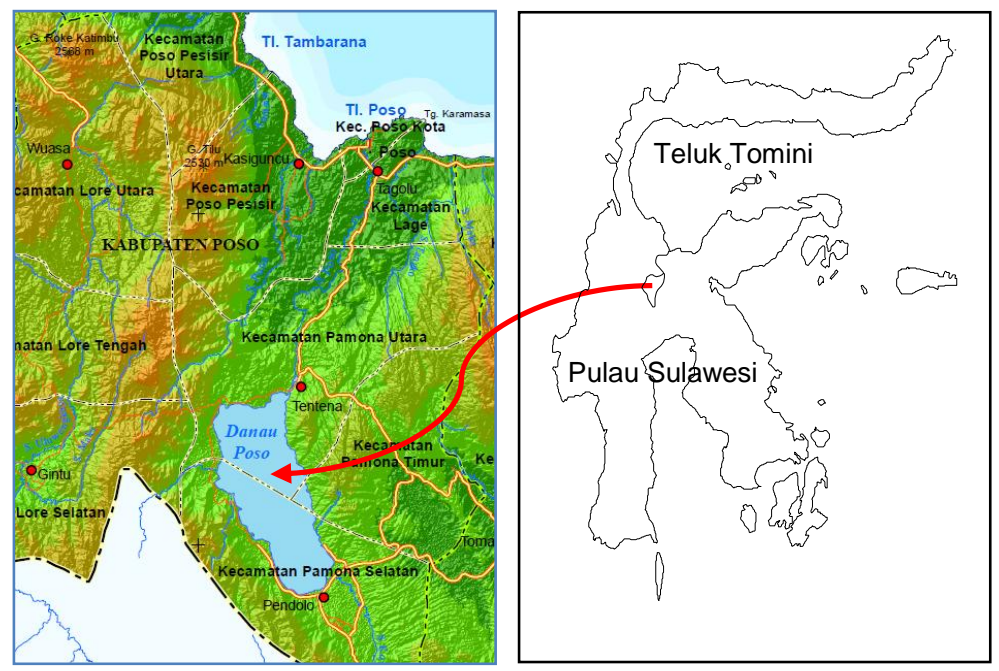

Gambar 1. Peta Danau Poso dan sekitarnya.

Sebagai bagian dari upaya untuk menghadirkan informasi ilmiah tentang kehidupan sidat di Danau Poso, penelitian ini diarahkan untuk mengungkapkan biostatistik sidat yang telah matang gonad atau yang dikenal dengan sebutan sidat perak (silver eel). Pengamatan difokuskan pada aspek-aspek: komposisi jenis, ukuran panjang dan berat, jenis kelamin, dan tingkat kematangan gonad dari sidat perak yang mulai bermigrasi dari Danau Poso menuju tempat pemijahannya di laut. Hasil penelitian ini diharapkan dapat meletakan dasar-dasar bagi kajian tentang upaya melestarikan populasi sidat di Danau Poso.

\section{Metode Penelitian}

\section{Pengumpulan Sidat Perak}

Sample sidat perak (silver eel) dikumpulkan dari hasil tangkapan alat sero tanam yang banyak terpasang di muara (out let) Danau Poso, dan yang dioperasikan oleh nelayan setempat. Alat tersebut terpasang dengan bukaan sayap menghadap ke arah danau (Gambar 2), maka besar kemungkinan bahwa sidat perak yang tertangkap adalah yang sedang mengawali migrasi pemijahan menuju ke laut (Teluk Tomini). Sidat perak dibedakan dari sidat muda (yellow eel) berdasarkan ciri-cirii; diameter mata relatif membesar dan warna punggung cenderung coklat tua sampai kelabu tua sedang bagian perut berwarna putih keperak-perakan (Feuteun, et al. 2000). Pengumpulan sidat perak dilakukan dalam kurun waktu Februari 2008 - Mei 2009. 


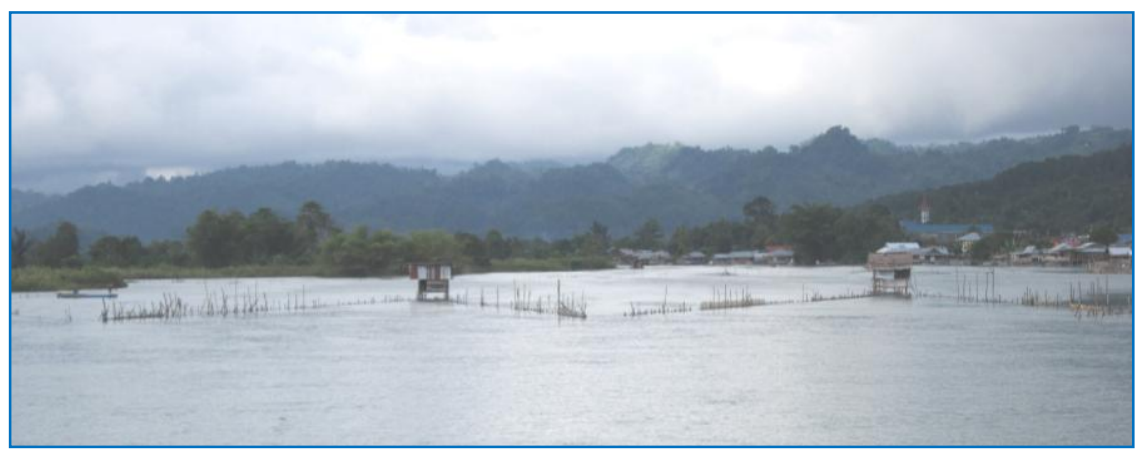

Gambar 2. Sero Tanam di muara Danau Poso.

\section{Pengukuran Morfometri}

Beberapa pengukuran; berat tubuh $(\mathrm{W})$, berat gonad (GW) dan panjang tubuh seperti pada Gambar 3 (predorsal $=\mathrm{PDL}$, preanal $=\mathrm{PAL}$, dan total $=\mathrm{L}$ ), dilakukan pada setiap sample sidat perak yang diperoleh.

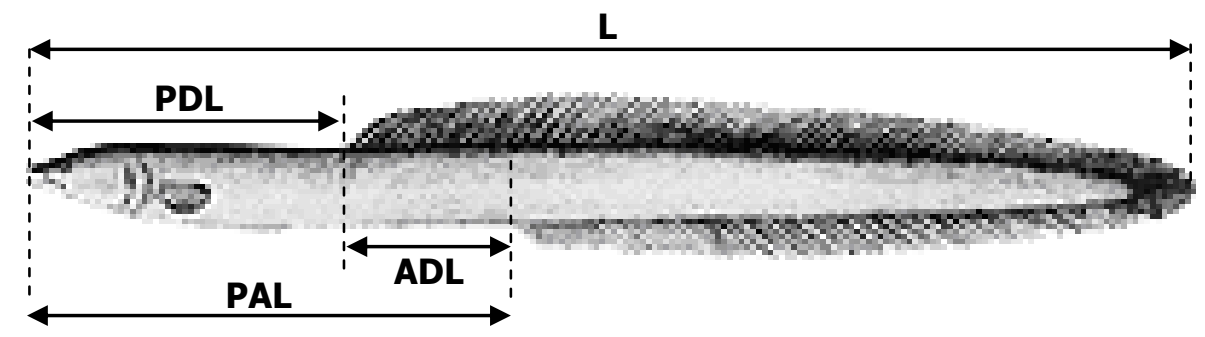

Gambar 3. Pengukuran komponen panjang sidat perak.

Identifikasi jenis (species) dari sample sidat perak dilakukan berdasarkan Index Anodorsal (IA) yang dihitung sebagai berikut :

$$
\mathrm{IA}=(\mathrm{AD}) /(\mathrm{L}) \times 100 .
$$

Hubungan panjang $(\mathrm{cm})$ dan berat $(\mathrm{g})$ sidat perak dievaluasi dengan metode least square dan persamaan yang digunakan adalah exponensial, yang dirumuskan sebagai berikut :

$$
W=a \cdot L^{b}
$$

dimana a dan $\mathrm{b}=$ parameter (konstanta). Berdasarkan persamaan hubungan panjang berat tersebut, dilakukan analisis faktor kondisi yang mencerminkan kegemukan dari sidat perak. Faktor kodisi (K) tersebut dihitung berdasarkan rumus :

$$
\mathrm{K}=\mathrm{W} / \mathrm{W}
$$

dimana $\hat{W}=a \cdot L^{b}$, yaitu berat yang diestimasi berdasarkan hubungan panjang berat. Asumsi yang digunakan dalam analisis ini, bahwa sidat perak yang beratnya lebih besar dari pada berat rerata pada kelas panjangnya - yang ditetapkan 
dengan persamaan hubungan panjang berat - dikategorikan berkondisi baik atau gemuk (nikai $\mathrm{K}>1$ ). Sebaliknya jika nilai $\mathrm{K}<1$ dikategorikan kurus.

Selain dengan kharakter morfologi eksternal yang telah disebutkan, identifikasi jenis kelamin sidat perak juga dilakukan berdasarkan kondisi gonadnya. Gonad betina berwarna putih dengan garis-garis kemerahan dan memperlihatkan pembentukan butiran-butiran. Gonad jantan berwarna putih polos dan tidak memperlihatkan pembentukan butiran-butiran (Gambar 4). Tingkat kematangan gonad dari sidat perak di ukur berdasarkan Gonadosomatic Index (GSI) yang dihitung dengan rumus :

$$
\mathrm{GSI}=\mathrm{GW} /(\mathrm{W}-\mathrm{GW}) \times 100
$$

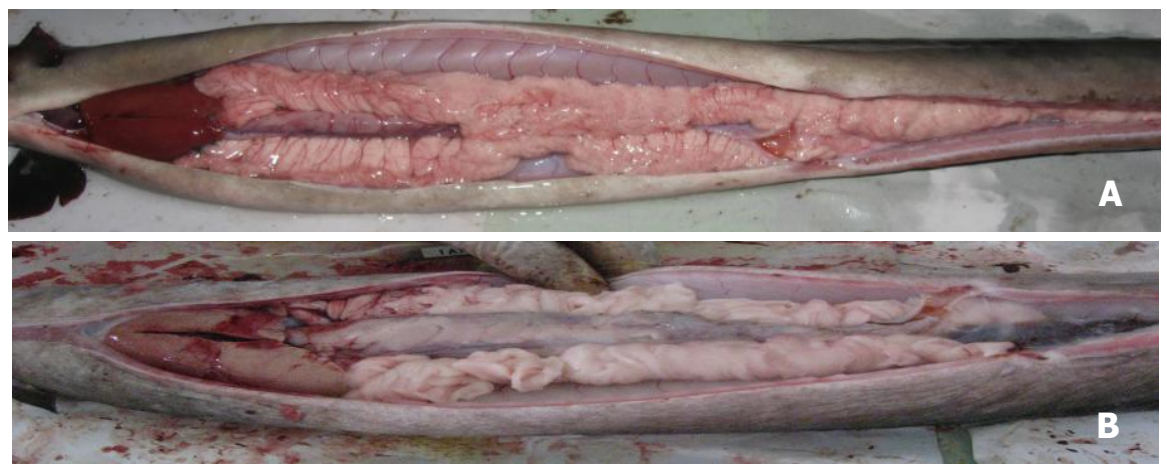

Gambar 4. Gonad betina (A) dan gonad jantan (B).

\section{Hasil dan Pembahasan}

\section{Identifikasi Jenis}

Sebanyak 100 individu sidat perak berhasil dikumpulkan dalam kurun waktu Februari 2008 - Mei 2009. Rincian jumlah dan ukuran sample sidat perak tersebut diberikan pada Tabel 1. Nampaknya, migrasi pemijahan sidat perak dari Danau Poso dapat terjadi sepanjang tahun khususnya pada musim hujan.

Distribusi frequensi Index Anodorsal (IA) dari sample sidat perak pada Gambar 5 dengan jelas menunjukan adanya dua modus. Hal ini, memberi indikasi yang kuat bahwa sample sidat perak tersebut terdiri dari dua kelompok (species). Mengacu pada Ege (1939) dan Tesch (1977), individu dengan nilai IA antara 13-19 dapat dikategorikan sebagai Anguilla marmorata, sedang yang bernilai antara 7-12 merupakan kharakter dari $A$. celebesensis, $A$. borneensis dan $A$. anterioris. Sambil menunggu klarifikasi berdasarkan analisis DNA terhadap sample sidat perak yang ada, dalam tulisan ini, kelompok kedua tersebut akan dikategorikan sebagai $A$. celebesensis. Hal ini didasarkan pada peta penyebaran sidat dunia yang dikemukakan dalam Ege (1939) dan Tesch (1977) yang mengindikasikan bahwa daerah Poso bukanlah termasuk wilayah penyebaran $A$. borneensis dan $A$. anterioris. 
Tabel 1. Jumlah dan ukuran sample sidat perak.

\begin{tabular}{cccc}
\hline $\begin{array}{c}\text { Jumlah } \\
\text { Sample }\end{array}$ & Bulan & $\begin{array}{c}\text { Berat (g) } \\
\text { (rerata) }\end{array}$ & $\begin{array}{c}\text { Pjg. Total (mm) } \\
\text { (rerata) }\end{array}$ \\
\hline \multirow{2}{*}{19} & Feb. 2008 & $\begin{array}{c}500-2550 \\
(1100,5)\end{array}$ & $\begin{array}{c}601-1039 \\
(782,9)\end{array}$ \\
& & $548-3121$ & $634-1123$ \\
12 & Okt. 2008 & $(1452,9)$ & $(843,5)$ \\
& & $398-2147$ & $526-1153$ \\
13 & Nov. 2008 & $(1195,5)$ & $(777,7)$ \\
& & $375-4527$ & $575-1215$ \\
16 & Jan. 2009 & $(1388,3)$ & $(824,7)$ \\
& & $265-7025$ & $520-1368$ \\
16 & Feb. 2009 & $(1076,3)$ & $(718,1)$ \\
& & $300-6100$ & $489-1242$ \\
24 & Mei 2009 & $(1481,3)$ & $(769,9)$ \\
\hline
\end{tabular}

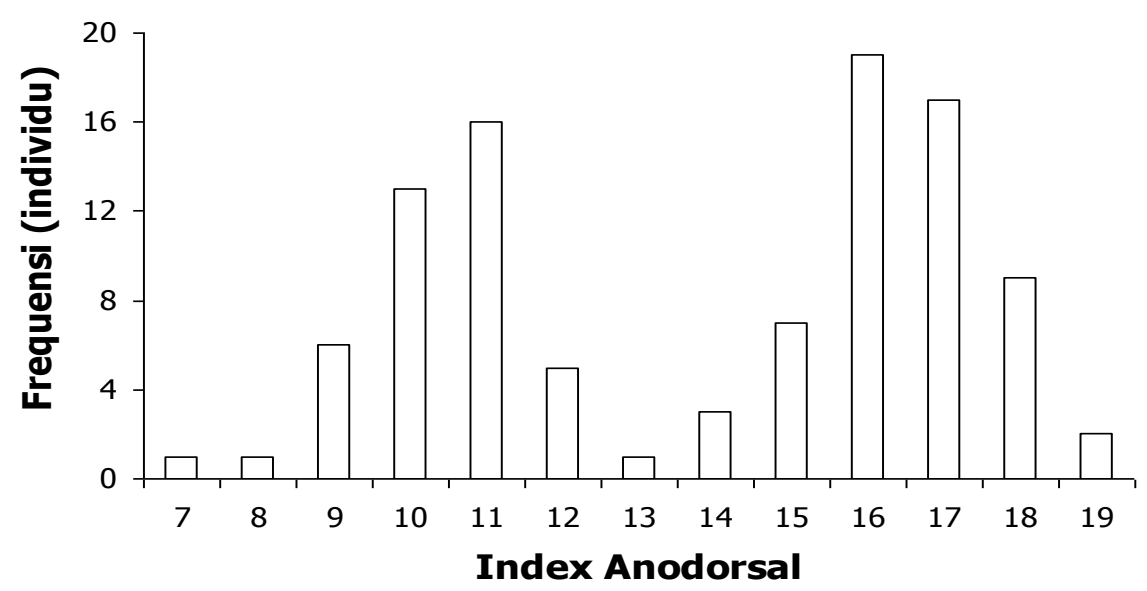

Gambar 5. Distribusi frequensi Index Anodorsal sidat perak.

\section{Tingkat Kematangan Gonad}

Hasil perhitungan Godanosomatic Index (GSI) berkisar antara $0-11,2 \%$. Dalam analisis selanjutnya, hanya individu dengan GSI $>1 \%$ yang digunakan, dan jumlahnya 63 ekor. Jumlah setiap species pada setiap bulan sampling diberikan pada Tabel 2. Berdasarkan, jumlah totalnya, sidat perak $A$. celebesensis jauh lebih banyak dibanding $A$. marmorata, tetapi proporsi bulanannya berfluktuasi. Tangkapan (sample) sidat perak terbanyak terjadi pada bulan Februari 2008 dan Februari 2009. Kuat dugaan bahwa hal ini berkaitan dengan naiknya ketinggian permukaan air Danau Poso yang memicu sidat perak untuk melakukan migrasi pemijahan. Fenomena ini juga dilaporkan dalam Sugeha (2003). Feunteun, et al. (2000) juga menemukan hal serupa di Sungai Fremur (Perancis Barat). 
Tabel 2. Komposisi species bulanan sidat perak.

\begin{tabular}{cccc}
\hline \multirow{2}{*}{ Bulan } & \multicolumn{3}{c}{ Jumlah Sidat Perak } \\
\cline { 2 - 4 } & A. celebesensis & A. marmorata & Total \\
\hline Feb. 2008 & $17(89 \%)$ & $2(11 \%)$ & 19 \\
Nov. 2008 & $1(14 \%)$ & $6(86 \%)$ & 7 \\
Jan. 2009 & $8(61 \%)$ & $5(39 \%)$ & 13 \\
Feb. 2009 & $15(94 \%)$ & $1(6 \%)$ & 16 \\
Mei 2009 & 0 & $8(100 \%)$ & 8 \\
\hline Total & $41(65)$ & $22(35 \%)$ & 63 \\
\hline
\end{tabular}

Seluruh sample sidat $A$. celebesensis dan $A$. marmorata teridentifikasi berkelamin betina. Fenomena ini sejalan dengan kesimpulan Tech (1977), bahwa semakin jauh ke arah hulu, proporsi sidat betina semakin meningkat. Cullen and McCarthy (2007) juga melaporkan dominasi sidat jantan pada bagian hilir Sungai Shannon (Irlandia). Apakah bagian hilir Sungai Poso merupakan habitat populasi sidat perak jantan, merupakan hal penting untuk diselidiki lebih lanjut.

GSI sidat perak $A$. celebesensis berkisar 4,77-12,58 dengan rerata 8,16 yang berbeda nyata dengan rerata $A$. marmorata sebesar 2,56 dengan kisaran $1,03-4,6$ (Gambar 6). Hal ini mengindikasikan bahwa sidat perak $A$. celebesensis memulai migrasi pemijahannya setelah mencapai tingkat kematangan gonad yang jauh lebih tinggi dibanding $A$. marmorata. Dengan demikian, tempat pemijahan $A$. celebesensis relatif dekat, sehingga tidak memerlukan waktu yang lama untuk mencapainya. Temuan ini sejalan dengan hipotesis Miller, et al. (2002) dan Aoyama, et al. (2003) tentang tempat pemijahan sidat tropis (Gambar 7).

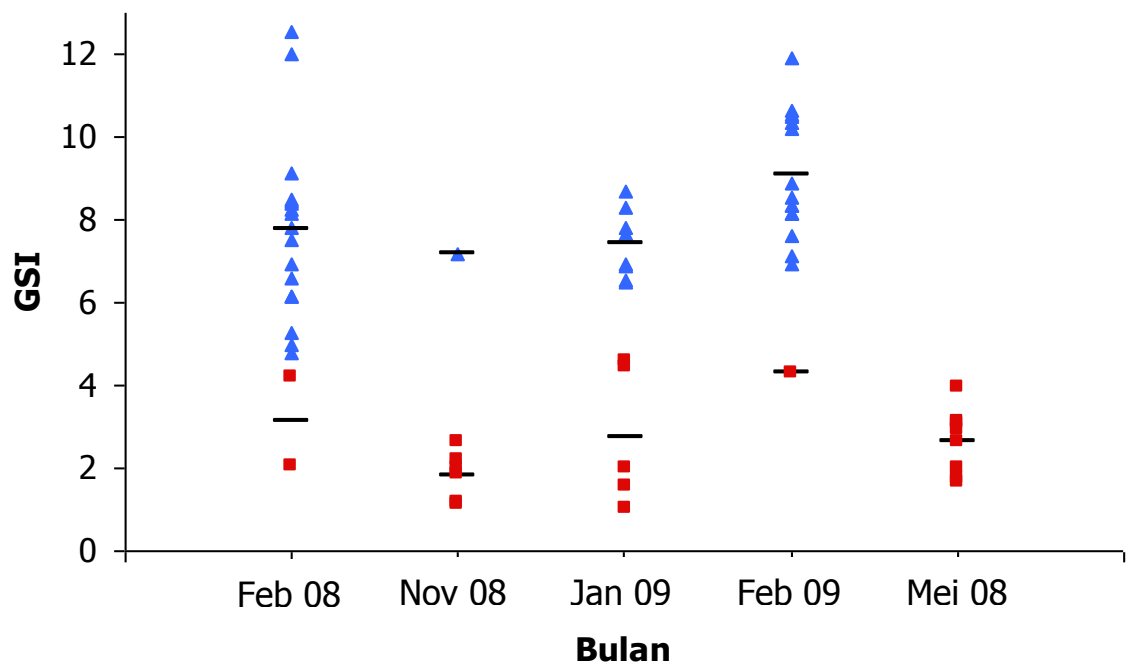

Gambar 6. Sebaran GSI A. celebesensis ( $\boldsymbol{\Lambda})$ dan A. marmorata ( $\square$ ), serta reratanya $(-)$. 


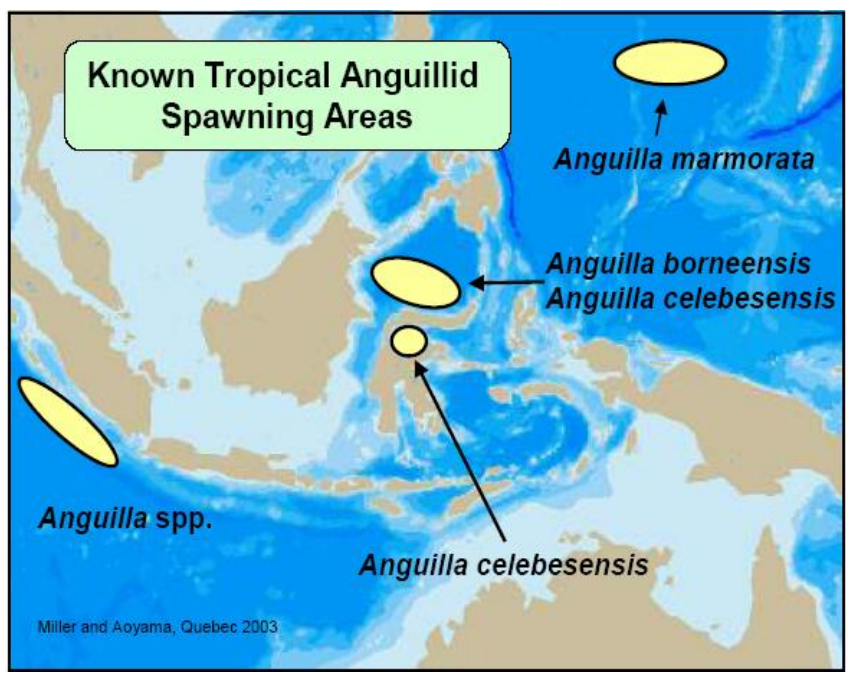

Gambar 7. Tempat pemijahan sidat tropis (Miller, et al. 2002; Aoyama, et al. 2003).

\section{Panjang, Berat dan Faktor Kondisi}

Rerata panjang dan berat tubuh sidat perak $A$. marmorata jauh lebih besar dari $A$. celebesensis, sebagaimana yang terlihat pada Gambar 8. Agaknya fenomena ini merupakan implikasi dari faktor genetik. Hubungan panjang dan berat kedua species cukup baik dijelaskan dengan model eksponensial.

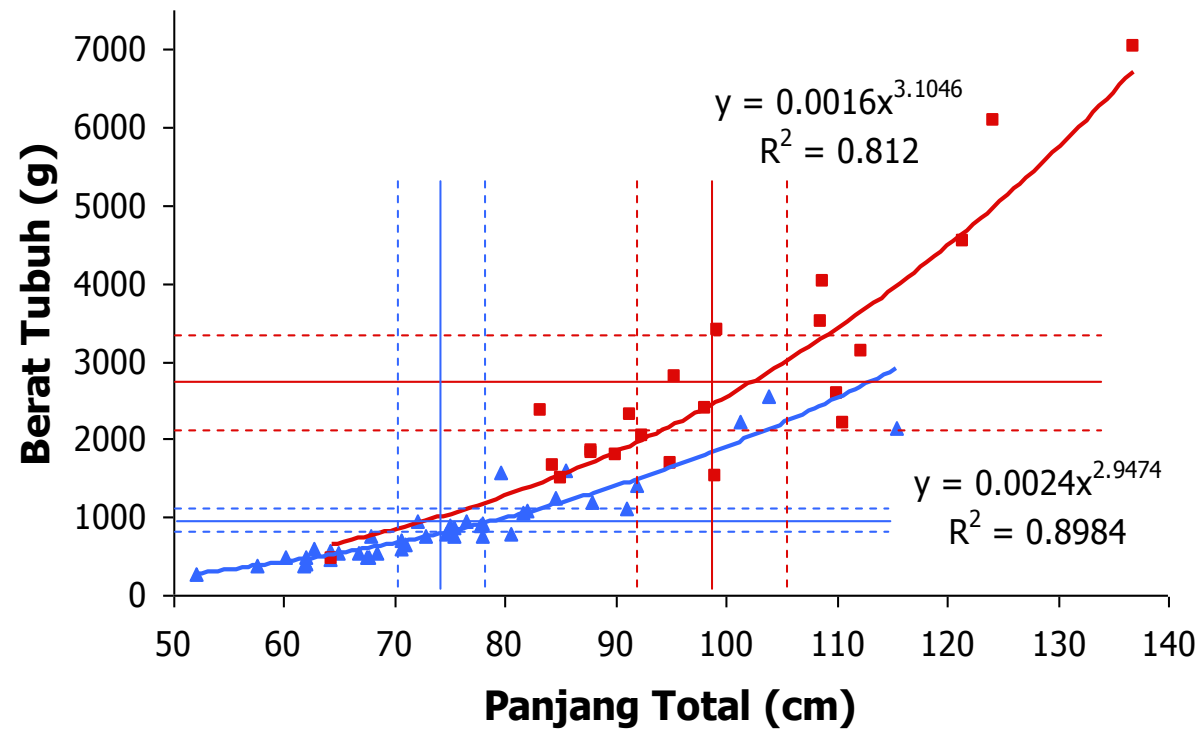

Gambar 7. Hubungan panjang-berat, rerata ( - ) dan konfiden interval $95 \%(---)$, A. celebesensis ( $\Delta$ ) dan A. marmorata ( $\square)$. 
Silver eel, Poso Lake, Indonesia.

Dibandingkan dengan data sidat tahun 2001, rerata panjang total kedua species cenderung menurun. Meskipun penurunan tersebut tidak signifikan pada konfiden interval 95\% (Gambar 9), namun dikaitkan dengan trend penurunan hasil tangkapan nelayan, maka hal ini merupakan indikasi telah terjadinya penangkapan lebih (over fishing) dan degradasi lingkungan perairan.

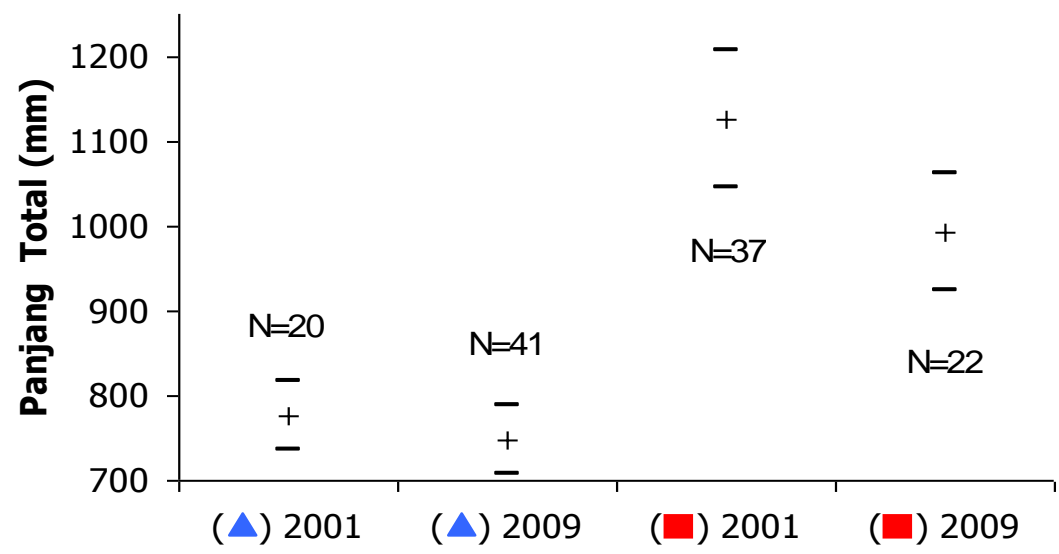

Gambar 9. Rerata (+) dan konfiden interval 95\% (-) dari panjang total $A$. celebesensis ( $\boldsymbol{\Delta}$ ) dan A. marmorata ( $\square$ ) tahun 2001 dan 2009.

Faktor kondisi merupakan indikator kegemukan ikan, sehingga memberikan gambaran mengenai ketersediaan pakan pada beberapa waktu sebelum ikan tersebut ditangkap. Dari hasil perhitungan faktor kondisi sidat Danau Poso (Gambar 10), terlihat bahwa rerata faktor kondisi $A$. celebesensis dan $A$. marmorata pada setiap bulan cenderung sama yang berfluktuasi disekitar garis normal $(K=1)$, pada bulan Nov. 2008 dan Jan. 2009 berada dibawah garis normal tersebut.

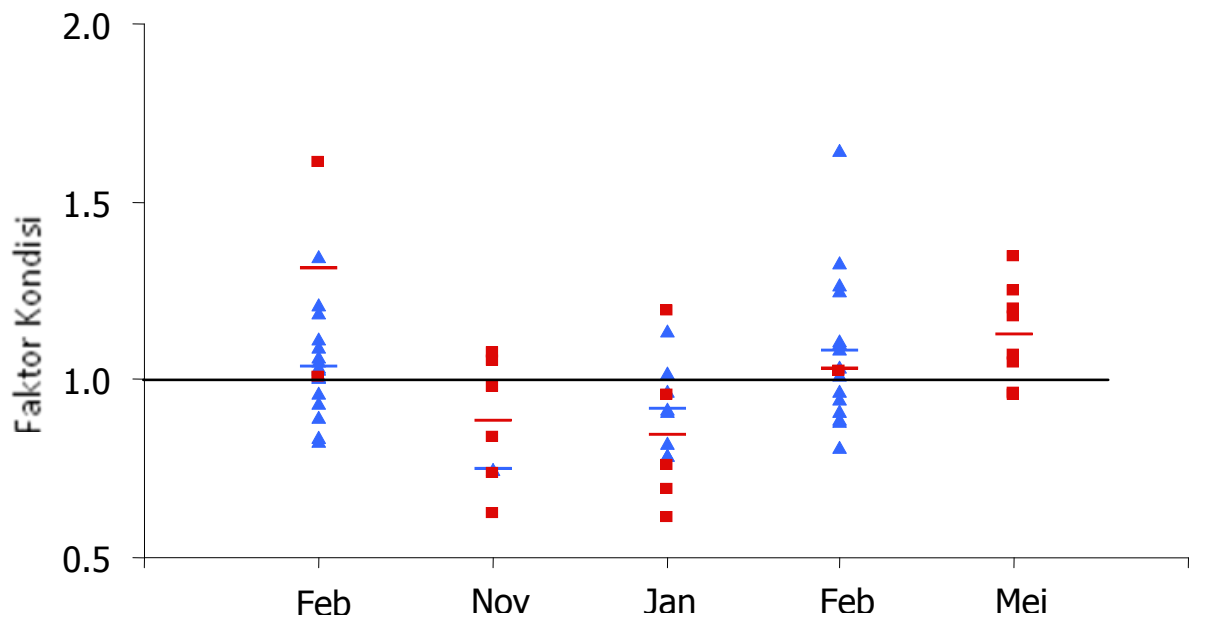

Bulan

Gambar 10. Sebaran dan rerata $(-)$ faktor kondisi $A$. celebesensis $(\Delta)$ dan A. marmorata ( $\square$ ). 


\section{KESIMPULAN}

Beberapa kesimpulan yang dapat dikemukakan sehubungan dengan hasil kajian ini adalah sebagai berikut :

1. Migrasi pemijahan sidat perak dari Danau Poso terjadi sepanjang tahun, dan cenderung memuncak pada musim hujan.

2. Kematangan gonad $A$. Celebesensis yang jauh lebih matang dari $A$. Marmorata memperkuat hipotesa tempat pemijahan kedua species tersebut berbeda, seperti ditunjukan pada Gambar 7.

3. Fenomena dominasi sidat betina di Danau Poso masih merupakan pertanyaan yang perlu mendapat perhatian untuk diteliti lebih jauh.

4. Sidat perak $A$. marmorata memiliki ukuran tubuh (panjang dan berat) yang lebih besar dari $A$. Celebesensis.

5. Kecenderungan penurunan ukuran tubuh dari kedua species merupakan indikasi telah terjadinya kelebihan tangkap dan degradasi lingkungan perairan Danau Poso.

\section{UCAPAN TERIMA KaSIH}

Kegiatan penelitian ini terlaksana berkat dukungan pendanaan dari Kementerian Pendidikan Dan Kebudayaan Republik Indonesia melalui Direktorat Penelitian dan Pengabdian Kepada Masyarakat yang dibebankan pada DIPA (Daftar Isian Pelaksanaan Anggaran) Nomor : 0868.0/023-04.1/-/2009 tanggal 31 Desember 2008. Bantuan teknis lainnya diperoleh dari Prof. Nobuyuki Miyazaki dan Dr. Takaomi Arai, Ocean Research Institute, The University of Tokyo serta Dinas Kelautan Dan Perikanan Kabupaten Poso.

\section{Daftar Pustaka}

Aoyama J, Wouthuyzen S, Miller MJ, Inagaki T, Tsukamoto K. 2003. Short-distance spawning migration of tropical freshwater eels. Biological Bulletin 204:104-124.

Cullen P, McCarthy TK. 2007. Eels Anguilla anguilla (L) of the lower River Shannon, with particular reference to seasonality in their activity and feeding ecology. Biology and Environment: Proceedings of The Royal Irish Academy. Vol.107B, 2:87-94.

Ege V. (1939). A revision of the genus Anguilla Shaw: A systematic, phylogenetic and geographical study. Dana Report 16:1-256.

Feunteun E, Acou A, Laffaille P, Legault A. 2000. European eel Anguilla anguilla: prediction of spawner escapement from continental population parameters. Can. J. Fish. Aquat. Sci. 57:1627-1635.

Miller MJ, Mochioka N, Otake T, Tsukamoto K. 2002. Evidence of a spawning area of Anguilla marmorata in the western North Pacific. Marine Biology, 140:809-814.

Sugeha HY. (2003). Life history of the tropical eel, Anguilla marmorata, in the Indonesian waters. PhD Dissertation, The University of Tokyo.

Tesch FW. (1977). The Eel: Biology and Management of Anguillid Eels. London: Chapman \& Hall. 